\title{
The Effect of Psychodrama on Subjective Well-Being and Trait Anxiety
}

\author{
Ayşe Nur Katmer \\ Department of Educational Sciences, Gaziantep University \\ P.O. Box 27310, Üniversite Bulvarı Şehitkamil Gaziantep, Turkey \\ Tel: 90-543-8202043Ｅ-mail: anurcetin@hotmail.com \\ Ramazan Demir \\ Department of Educational Sciences, Gaziantep University \\ P.O. Box 27310, Üniversite Bulvarı Şehitkamil Gaziantep, Turkey \\ Tel: 90-551-4330613 E-mail: rd_1991@hotmail.com
}

Ali Çekiç (Corresponding author)

Department of Educational Sciences, Gaziantep University

P.O. Box 27310, Üniversite Bulvarı Şehitkamil Gaziantep, Turkey

Tel: 90-505-2369906_E-mail: alicekic79@gmail.com

\author{
Zeynep Hamamcı \\ Department of Educational Sciences, Gaziantep University \\ P.O. Box 27310, Üniversite Bulvarı Şehitkamil Gaziantep, Turkey \\ Tel: 90-533-5164462 E-mail: hamamci@gantep.edu.tr
}

Received: August 28, 2020 Accepted: October 13, 2020 Published: October 26, 2020

doi:10.5296/jei.v6i2.17600 URL: https://doi.org/10.5296/jei.v6i2.17600

\section{Abstract}

This study investigates the effects of psychodrama on adults' anxiety and subjective 
well-being levels. A pre/post-test experimental pattern is used with experimental and control groups. The study sample consists of 24 non-thesis master's program students at Gaziantep University, Human Psychology, and Communication. The State-Trait Anxiety Inventory (STAI) and the Subjective Well-Being Scale were applied as a pre-test to the experimental and control groups. The psychodrama group practice was performed with the experimental group once a week for eleven weeks, 90 minutes per session, while the control group did not receive any practice. After the application, the post-test was administered to both groups. The data were analyzed with SPSS 23 statistical program. The Mann-Whitney U test was used to evaluate the difference between the experimental and control group, and the Wilcoxon Signed Rank Test was applied for the changes within the experimental group. The findings indicate that the individuals' anxiety level in the experimental group significantly decreased compared to the control group. There was no significant difference between subjective well-being in the experimental and control group for pre-test and post-test applications.

Keywords: Psychodrama, Anxiety, Subjective well-being, Psychology, Group therapy

\section{Introduction}

Today, individuals' mental health is characterized by the well-being concept coupled with the effect of positive psychology. Well-being is defined as "an individual being good and in a healthy mood with complete functioning in physical, mental and spiritual terms and maintaining an active life in the social and natural environment" (Kardaş \& Yalçın, 2019). Korkut-Owen and Owen (2012) developed a model to explain well-being; this consisted of five dimensions of well-being, comprising emotional, social, physical, cognitive, the meaning of life, and goal-oriented. Among these dimensions, emotional well-being includes properties such as being aware of and controlling emotions and seeing self, life circumstances, and conflicts in the realistic, positive, and developmental way (Korkut-Owen, Doğan, Demirbaş-Çelik, \& Owen, 2016).

Another important concept related to spiritual well-being is subjective well-being. Diener and Eunkook (2003) defined subjective well-being as individuals' assessing their lives with positive concepts. In other words, subjective well-being is used for defining the well-being level of individuals based on subjective assessments, which could be positive or negative. The term includes judgments and emotions in life satisfaction, interest and responsibility, affective reactions to life such as joy and sadness, purpose and meaning in business relationships, health and entertainment, and in other important fields (Diener \& Ryan, 2018). If people are content with their lives, frequently experience positive emotions, and experience few negative emotions, they are well in subjective terms. In other words, these people have high subjective well-being (Eryllmaz, 2010).

In the literature, various studies have assessed the relationship between subjective well-being levels and numerous variables. While some of them investigated the effect of demographic properties such as age, gender on subjective well-being (Eryllmaz \& Ercan, 2011; Gündoğdu \& Yavuzer, 2012), other studies analyzed the effects of self-respect (Doğan \& Eryılmaz, 2013), interpersonal relationships (Doğan \& Sapmaz, 2012), social support (Saygın \& Arslan, 2009), social skills (Canbay, 2010) and decision-making skills (Dilmaç \& Bozgeyikli, 2009) 
on subjective well-being.

Another variable that might be related to subjective well-being is anxiety, which is a negative emotion. Anxiety is defined as sadness, sorrow mixed with worry. In general, it involves a natural anxiousness, tension, fear, and distress which individuals can face in daily life (Çivilidağ et al., 2018).

Öner and Le Compte (1983) believed that anxiety can be divided into state-trait anxiety and trait anxiety. State-trait anxiety is the subjective fear stemming from a stressful situation. While the state-trait anxiety increases under high-stress situations, it decreases when stress is removed. While the fear and uneasiness based on dangerous situations are accepted as temporary and normal anxiety, state-trait anxiety, which is not directly linked to existing situation, describes a personality characteristic. Because state-trait anxiety is the tendency of the individual to lead a troubled life, these individuals might experience state-trait anxiety more frequently and intensely than other individuals (Cited by Aslan, 2007). Studies in the literature showed a negative relationship between subjective well-being and state and trait anxiety (Öztürk, 2013; Tangör \& Curun, 2016). Although these two concepts are often used together, they express different characteristics. While "state anxiety" is defined as a temporary reaction to adverse events, "trait anxiety" is a more detailed personality trait in a one-person order related to the tendency to respond to various situations with anxiety, distress, and question (Saviola et al., 2020). It is possible to say that as the level of negative emotions, such as anxiety, decreases, an individual's subjective well-being increases.

Another factor affecting subjective well-being is finding solutions to the problems people face and gaining skills to cope with them. The individuals' problem-solving skills might have significant contributions to experiencing positive emotions, increasing life satisfaction, improving subjective well-being, and mood. Studies in this field determine the relationships between coping skills and subjective well-being. Eryllmaz (2009) conducted a model study with adolescents to measure the mediator role of coping strategies on subjective well-being and personal characteristics. The study results indicated that extrovertism and emotionally unstable personal characteristics, and emotion- and problem-oriented coping affected adolescent subjective well-being. In other research, an active coping skill, which refers to practical and functional problem-solving capability, is essential to increase adolescent subjective well-being (Işı \& Bedel, 2015). The authors showed that efforts to develop the problem-solving skills of individuals could help improve personal well-being levels.

The studies on subjective well-being in the literature have mainly applied a psycho-education curriculum to realize and express emotions (Kuzucu, 2006), increase forgiveness tendency (Çardak, 2012), improve social skills (Gülaçt1, 2009), gainlife skills (Ümmet-Demirci, 2017), cope with death anxiety (Tanhan, 2007) and search for meaning (Ok, 2016). It can be seen that experience-oriented group psychology counseling practices to increase subjective well-being are limited (Agha-Bagheri, Mohammad-Khani, Emrani, \& Farahmand, 2012; Arsu, Erbay, Ünal, Erbay, \& Gürgan, 2018; Duran \& Tezer, 2007; S. Kim, G. Kim, \& Ki, 2014).

One of the experience-oriented methods to increase subjective well-being is psychodrama. Psychodrama is a psychotherapy method in which clients express the critical events in their 
life with actions rather than talking. In other words, it is the replay of life (Blatner, 2000). Individuals who participate in psychodrama can re-live the crucial things for them in the group. According to Moreno, repeating certain scenes during psychodrama has a healing and treating function. Creativity plays a vital role in the theoretical foundation of psychodrama. According to Moreno, the purpose of psychodrama is to uncover the creative skill of a person. Only then can people be constructive and creative and adapt to new conditions (Özbek \& Leutz, 1987). The primary purpose of psychodrama's techniques is to increase individuals' spontaneity and, thus, enhance their creativity (Blatner, 2000). With psychodrama, it is possible to improve spontaneity, helping individuals find different solutions to problems, gain creativity, try new behaviors, and develop positive emotions and moods.

There are some studies in the literature that use psychodrama methods to improve individual subjective well-being levels. Conducted on university students, they found that psychodrama-based group consultancy effectively improved university students' subjective well-being (Albayrak, 2013; Karataş, 2014; Kaya \& Deniz, 2020; Mosavi \& Haghayegh, 2019; Tavakoly, Namdari, \& Esmaili, 2014). Some studies investigated whether psychodrama is an effective method to decrease state-trait anxiety, another concept related to subjective well-being. Studies on high-school students (Karataş, 2009) and depressive patients (Erbay et al., 2018) showed that psychodrama is an effective method to decrease both state-trait and trait anxiety. Psychodrama is seen as a powerful method to relieve the general anxiety symptoms in the clients (Görkem \& Tüccar, 2018; Kandemirci-Bay1z \& Kalkan-Oğuzhanoğlu, 2020; Nazar, Bahramabadi, Delavar, \& Gilan, 2014; Terzioğlu \& Özkan, 2018; Wang, 2020).

When the studies related to subjective well-being are investigated, it can be seen that the majority of them were conducted on high-school or university students, and there was a limited number of studies on different occupational groups from the different segments of the society (Kardaş \& Yalçın, 2018). The majority of the studies on improving subjective well-being with life techniques such as psychodrama have been conducted on university students. However, the literature emphasizes the importance of subjective well-being for individuals in the different development periods (Cited by Eryllmaz, 2014). Adulthood includes a series of life requirements, including romantic relationships, marriage, work, having a child, and responsibilities and problems associated with these factors. Marriage, financial conditions, and career-related stress are some of the challenges in adulthood (Korkut-Owen \& Demirbaş-Çelik, 2018). Therefore, adults need practices to contribute to subjective well-being levels and moods to solve the life problems they experience.

The study aims to investigate whether psychodrama affects adult subjective well-being and trait anxiety levels. Based on this general purpose, the following hypotheses were tested.

(1) Individuals participating in psychodrama will experience a decrease in trait anxiety levels compared to individuals not participating in psychodrama.

(2) Individuals participating in psychodrama will experience an increase in subjective well-being levels compared to individuals not participating in psychodrama. 


\section{Method}

\subsection{Research Model}

This experimental study had a semi-experimental design, including experimental and control groups, and used pre-test and post-test measurement (Büyüköztürk, 2007). In this design, while the first factor indicates the independent process groups (experimental and control), another factor indicates the repetitive measurements (pre-test and post-test) under different conditions for the dependent variable. The research pattern is given in Table 1 .

Table 1. Research pattern

\begin{tabular}{|l|l|l|l|}
\hline Groups & Pre-test & Process & Post-test \\
\hline \multirow{3}{*}{ Experiment } & STAS & Psychodrama & STAS \\
\cline { 2 - 4 } & SWBS & & SWBS \\
\hline \multirow{3}{*}{ Control } & STAS & - & STAS \\
\cline { 2 - 4 } & SWBS & & SWBS \\
\hline
\end{tabular}

Note. TAS: The Trait Anxiety Scale; SWBS: The Subjective Well-Being Scale.

Based on this pattern, the study has one independent and two dependent variables. The study's independent variable was psychodrama, and the dependent variables were subjective well-being and state-trait anxiety levels. The repetitive measurements were separately analyzed for the two dependent variables. The Subjective Well-Being Scale (SWBS) and the Trait Anxiety Scale (TAS) were applied to the experimental and control groups before the psychodrama. One week after the 11-week counseling with the experimental group, the instruments were administered to both groups again. When the psychodrama was performed with the experimental group, there was no application with the control group, and the theoretical curriculum was followed. Neither group received classes for personal development in their curriculum.

\subsection{Study Group}

The experimental and control groups were selected among voluntary students from the non-thesis master's program of the Human Psychology Department at Gaziantep University in the 2019-2020 academic term. A preliminary interview was held with the individuals in the current program before the study. In the preliminary interview, information was given about the purpose of the study, its achievements, duration, frequency of being done and meeting place. Information was obtained from the volunteers via the form prepared to evaluate their eligibility for participation in the study. In the last stage, a study group was formed from volunteer participants who did not have any psychiatric problems and who had not received psychological counseling service recently. Psychodrama is a form of practice in which all 
participants actively participate in the process. With the techniques and methods used in the working process, every participant is active in the process. Participants work as a group in the sessions and stay alive without getting bored throughout the session. While a total of 14 individuals, among which six were female and eight were male, were included in the experiment group, 14 individuals, among which nine were female and five were male, were included in the control group. While the participants' ages ranged between 22 and 44 years, the average age was 30 years $(\mathrm{Sd}=6.68)$.

\subsection{Data Collection Tools}

In this study, the Trait Anxietysub-dimension of the State-Trait Anxiety Scale, and the Subjective Well-Being Scales were used for data collection.

\subsubsection{State-Trait Anxiety Scale}

State-Trait Anxiety Scale was developed by Spielberger, Gorsuch, and Lushene in 1964 to measure the state-trait and trait anxiety levels of individuals 14 years old or above. The Turkish adaptation study of the instrument was conducted by Necla Öner and Ayhan Le Compte (1977). The scale consisted of the "State-Trait Anxiety Scale" that determines how an individual feels at a particular time and conditions and "Trait Anxiety Scale" that determines how individuals generally feel, independent of the existing conditions. Each has 20 items, and is a Likert-type tool and scored between 1 and 4 (1-Almost never, 2-Sometimes, 3-Often, 4-Almost always). In the State-Trait Anxiety Scale, there are 10 inverse items which are 1, 2, 5, 8, 10, 11, 15, 16, 19 and 20; in Trait Anxiety Scale, there are seven inverse items which are 21, 26, 27, 30, 33, 36 and 39. For the total scale, the direct and inverse statements' scores are calculated separately; while the score for direct statements is added to the total score, the inverse statements are subtracted from the total score. A predetermined constant number is added to it. The constant value for the State-Trait Anxiety Scale is 50 and 38 for the Trait Anxiety Scale. The total scores from both scales range between 20 and 80 . While the high score indicates a high anxiety level, a low score indicates a low anxiety level (Öner, 2006). The scale reliability was found between 0.83 and 0.87 for the "Trait Anxiety Scale." Test/re-test reliability coefficients for the scale were between 0.71 and 0.86 for the "Trait Anxiety Scale" (Öner \& Le Compte, 1985). In this study, the "Trait Scale" section was used, because there was no unusual situation such as exams, unemployment, trauma experience, which can increase the anxiety level of both the experimental and the control group. Therefore, the Trait Anxiety sub-dimension was administered to measure the anxiety level considering the reactions to daily life events as a dependent variable and reflect various characteristics.

\subsubsection{Subjective Well-Being Scale}

Subjective Well-Being Scale was developed to measure individuals' mental status that is a cognitive factor, and the positive and negative emotions that comprise the emotional aspect. The instrument was developed by Dost (2005). It is a 5-point Likert-type scale and consists of 46 items (“(5) Completely Agree”, “(4) Mostly Agree”, “(3) SlightlyAgree”, “(2) Slightly Disagree" and "(1) Completely Disagree". The scale has 26 positive and 20 negative items, 
which are inversely coded. While the lowest score from the scale is 46 points, the highest score is 230 points. The low points indicate a low subjective well-being level, while high points indicate a high subjective well-being level. The Cronbach Alpha internal consistency is .93, and Pearson Product Moment Correlation is .86.

\subsection{The Experimental and Control Groups}

While 20 non-thesis master's program students in Gaziantep University, Human Psychology, and Communication Department who also took Group Dynamics and Intergroup Relationships course in 2019-2020 fall term comprised the experimental group, 18 students from the first term of the same program were selected as the control group. Since four participants in the experimental group failed to participate in sessions for more than three weeks, they were excluded; and as two students failed to participate in the post-test measurements within the specified time, they were also excluded from the analysis. Four students in the control group failed to participate in pre-test and post-test measurements within the specified time, and these students were excluded from the study. Thus, the study was completed with 14 experimental group students and 14 control group students.

\subsection{Psychodrama Program}

In this study, a 11-week psychodrama was experienced by the participants in the experimental group. The program was conducted once a week and for one and a half hours. It was completed in eleven sessions. Information about the sessions is given below.

(1) Session: The in-group meeting and group structuring were completed. Within this scope, meeting and activities were completed for the clients to make connections. The session was ended with impersonation called "tree statue."

(2) Session: The group warmed up, and meeting and structuring of the clients who were absent in the previous week were completed. In this session, the statue activity, which aimed to create a purpose, was completed. Four theme chairs were created and placed in front of the group, and everyone was asked to choose a chair. Individual and shared goals were determined in the group.

(3) Session: The session started with a warm-up activity. Two clients who want to talk about their topics for an in-depth study sat down in the middle of the group. The group members selected the chair they want to discuss and, thus, determined the topic. In this session, "challenges to take steps towards the goal and procrastination" topic was selected, and the group worked on it.

(4) Session: The session started after the warm-up activity. The topic of a client, "Caring what other people think less," was discussed. This session used "thought atom" activity. Following the activity, the session was ended after collecting the group members' sharing related to the session.

(5) Session: The session started with the warm-up activity. The group studied the "anger" topic mentioned by a group member. Role-playing and empty chair techniques of the psychodrama were used in this individual practice. 
(6) Session: When the two group members mentioned the "anxiety to lose relatives" topic, the group worked on it during the session.

(7) Session: The session started with a letter-writing activity. Then, the empty chair technique enabled voluntary group members to confront the person of whom they wrote.

(8) Session: "Making changes in life" topic was discussed as a result of the group's collective decision.

(9) Session: Following the collective decision of the group, "using time effectively" topic was worked.

(10) Session: "Relation with mother" topic of a group member was discussed. In this session, role-playing, mirror, and family photo techniques were used.

(11) Session: The summary of the process and participants' thoughts and feelings were collected. The "gossiping activity" was completed for group leader and group members assessments. The session was ended by considering the future expectations and goals of the members.

At the beginning of each session, members were asked about how the past week was and what they felt in that session, and the session was started with a warm-up activity. Besides, at the beginning of each session, activity purposes were explained, and their thoughts and ideas were taken.

\section{Results}

\subsection{Method}

The study data were first examined for normality conditions to determine the analysis method. Skewness and kurtosis values were investigated to test the normality hypothesis. Morgan (2004) and Şencan (2005) recommended that skewness and kurtosis values should be between -1 and +1 when interpreting the normality values. Since the data obtained from the scales did not have skewness and kurtosis values between -1 and +1 range, non-parametric tests were preferred. Mann-Whitney $U$ test was used for the difference between rank averages obtained from the pre-test, and post-test measurements of the experimental and control group and Wilcoxon Signed Rank Test were applied whether the differences between pre-test and post-test measurement score averages were significant.

Additionally, p-value and impact size were investigated in this study. The impact size is the unit of the relationship power between two variables (Borenstein, Hedges, Higgins, \& Rothstein, 2009). The impact size is low for $r<0.20$, medium for $20<r<50$, and high for $r$ $<50$ (Cohen, 1988). The data analysis was conducted on SPSS 23 program. For all analyses in this study, the significance level was .05.

\subsection{Findings}

The purpose of this study is to investigate the effects of psychodrama on adults' anxiety and subjective well-being level. Before testing the hypothesis, the trait anxiety scale and 
subjective well-being arithmetic average and standard deviation values of the experimental and control groups before and after the application were calculated. The values are presented in Table 2.

Table 2. Experimental and control group STAS and SWBS score distribution

\begin{tabular}{|c|c|c|c|c|c|c|}
\hline \multirow{2}{*}{\multicolumn{2}{|c|}{$\begin{array}{l}\text { Tests } \\
\text { Groups }\end{array}$}} & \multirow{3}{*}{$\begin{array}{l}n \\
14\end{array}$} & \multicolumn{2}{|c|}{ Pre-test } & \multicolumn{2}{|c|}{ Post-test } \\
\hline & & & $\overline{\mathrm{x}}$ & $\mathrm{Sd}$ & $\overline{\mathrm{x}}$ & $\mathrm{Sd}$ \\
\hline \multirow{2}{*}{ TAS } & Experimental & & 40.21 & 12.68 & 34.43 & 6.87 \\
\hline & Control & 14 & 42.43 & 7.67 & 41.86 & 8.63 \\
\hline \multirow{2}{*}{ SWBS } & Experimental & 14 & 178.21 & 32.50 & 198.29 & 20.66 \\
\hline & Control & 14 & 182.93 & 29.08 & 180.21 & 32.57 \\
\hline
\end{tabular}

Note. TAS: The Trait Anxiety Scale; SWBS: The Subjective Well-Being Scale.

Table 2 shows that the pre-test scores of the experimental group were lower than the post-test average of the control group. The average of the STAS pre-test scores of the control group was similar to the average score from the post-test. It can be seen that the average of the SWBS pre-test scores of the experimental group was lower than the post-test average of the control group. There was no change between SWBS pre-test and post-test average scores of the control group. In other words, while anxiety level decreased and subjective well-being increased in the experimental group after the psychodrama program, there was no change in the control group's anxiety level.

Non-parametric techniques were used to determine whether the change between the control and experimental group score averages were significant. In line with the study's purpose, the Mann-Whitney U test was applied to determine whether there was a significant difference between STAS and SWBS pre-test score averages of both groups. The Mann-Whitney U test results obtained from STAS and SWBS pre-test score averages of the experimental and control groups are given in Table 2. 
Table 3. The Mann-Whitney U test results related to 4TAS and SWBS pre-test score averages of the experimental and control groups

\begin{tabular}{|l|l|l|l|l|l|l|}
\hline & Group & $\mathrm{N}$ & Mean Rank & Total Rank & $\mathrm{U}$ & $\mathrm{p}$ \\
\hline \multirow{2}{*}{ TAS } & Experimental & 14 & 14.64 & 201.00 & 96 & .93 \\
\cline { 2 - 7 } & Control & 14 & 14.36 & 205.00 & & \\
\hline \multirow{2}{*}{ SWBS } & Experimental & 14 & 13.57 & 190.00 & 85 & .57 \\
\cline { 2 - 8 } & Control & 14 & 15.43 & 216.00 & & \\
\hline
\end{tabular}

Note. TAS: The Trait Anxiety Scale; SWBS: The Subjective Well-Being Scale.

When Table 3 was analyzed, it was seen that there was no significant difference between TAS $\left[\mathrm{U}_{(28)}=96, \mathrm{p}>.05\right]$ and SWBS $\left[\mathrm{U}_{(28)}=85, \mathrm{p}>.05\right]$ pre-test score averages of the experimental and control groups.

In line with the study's purpose, the Mann-Whitney U test was applied to determine whether there was a significant difference between TAS and SWBS post-test score averages of the experimental and control groups (Table 3).

Table 4. The Mann-Whitney U test results related to TAS and SWBS post-test score averages of the experimental and control groups

\begin{tabular}{|l|l|l|l|l|l|l|}
\hline & Group & $\mathrm{N}$ & Mean Rank & Total Rank & $\mathrm{U}$ & $\mathrm{p}$ \\
\hline \multirow{3}{*}{ TAS } & Experimental & 14 & 10.43 & 146.00 & 41 & .009 \\
\cline { 2 - 6 } & Control & 14 & 18.57 & 260.00 & & \\
\hline \multirow{2}{*}{ SWBS } & Experimental & 14 & 16.61 & 232.50 & 68.50 & .18 \\
\cline { 2 - 6 } & Control & 14 & 12.39 & 173.50 & & \\
\hline
\end{tabular}

Note. TAS: The Trait Anxiety Scale; SWBS: The Subjective Well-Being Scale.

According to Table 4, there was a significant difference between STAS post-test score averages between experimental and control groups [ $\mathrm{U}_{(28)}=41, \mathrm{p}<.05$ ]. When the impact size for the anxiety variable was considered, Cohen's $d=(41.86-34.43) / 7.799801=$ 0.952588 . $d>0.8$ value indicates a significant impact. Thus, it can be seen that the effect of the change in the anxiety variable was high.

There was no significant difference between SWBS post-test score averages between experimental and control groups $\left[\mathrm{U}_{(28)}=68.50, \mathrm{p}<.05\right]$.

To determine the source of that difference at trait anxiety levels between the experimental and 
control group before and after the psychodrama application, whether there was a difference between the TAS pre-test and the post-test score of the experimental and control group were analyzed with Wilcoxon Signed Rank Test (Table 4).

Table 5. Wilcoxon Signed-Rank Test results for TAS and SWBS pre-test and post-test score averages of the experimental group

\begin{tabular}{|l|l|l|l|l|l|l|}
\hline & Group & $\mathrm{N}$ & Mean Rank & Total Rank & $\mathrm{z}$ & $\mathrm{P}$ \\
\hline \multirow{4}{*}{ TAS (pretest-posttest) } & Negative & 11 & 8.05 & 88.50 & & \\
\cline { 2 - 6 } & Positive & 3 & 5.50 & 16.50 & \multirow{2}{*}{-2.26} & \multirow{2}{*}{.02} \\
\cline { 2 - 6 } & No difference & 0 & & & & \\
\hline \multirow{3}{*}{ SWBS (pretest-posttest) } & Negative & 2 & 5.57 & 11.00 & & \\
\cline { 2 - 7 } & Positive & 11 & 7.27 & 80.00 & -2.41 & .02 \\
\cline { 2 - 6 } & No difference & 1 & & & & \\
\hline
\end{tabular}

Note. TAS: The Trait Anxiety Scale; SWBS: The Subjective Well-Being Scale.

In Table, it can be seen that there was a significant difference in STAS $(z=-2.26, p<.05)$ and SWBS $(\mathrm{z}=-2.41, \mathrm{p}<.05)$ pre-test and post-test score averages of the experimental group.

The intragroup change for the control group before and after the program was analyzed with Wilcoxon Signed Rank Test, and the results are given in Table 5.

Table 6. Wilcoxon Signed-Rank Test results for TAS and SWBS pre-test and post-test score averages of the control group

\begin{tabular}{|l|l|l|l|l|l|l|}
\hline & Group & $\mathrm{N}$ & Mean Rank & Total Rank & $\mathrm{z}$ & $\mathrm{p}$ \\
\hline \multirow{4}{*}{ TAS (pretest-posttest) } & Negative & 8 & 7.25 & 58.00 & & \\
\cline { 2 - 6 } & Positive & 6 & 7.83 & 47.00 & \multirow{2}{*}{-.35} & .73 \\
\cline { 2 - 8 } & No difference & 0 & & & & \\
\hline \multirow{3}{*}{ SWBS (pretest-posttest) } & Negative & 9 & 7.67 & 69.00 & & \\
\cline { 2 - 8 } & Positive & 5 & 7.20 & 36.00 & -1.04 & .30 \\
\cline { 2 - 7 } & No difference & 0 & & & & \\
\hline
\end{tabular}

Note. TAS: The Trait Anxiety Scale; SWBS: The Subjective Well-Being Scale. 
According to Table 6 , there was no significant difference in STAS $(\mathrm{z}=-.35, \mathrm{p}<.05)$ and SWBS $(z=-1.04, p<.05)$ pre-test and post-test score averages of the control group.

\section{Discussion}

This study investigates the effect of psychodrama experience on adult subjective well-being and state-trait anxiety levels. The study results suggested that while psychodrama can relieve trait anxiety, it has no significant effect on subjective well-being.

The study results are in line with the other studies in the literature that show psychodrama is a practical for general personal anxiety. Erbay et al. (2018) conducted a 16-week psychodrama program on 18-65 years old adults diagnosed with depression and found that anxiety levels decreased after the program. Karataş (2009) stated that after a 10-week psychodrama application on the high-school students, students' state-trait anxiety levels decreased.

The primary feature of anxiety disorder is the sympathetic nervous system's stimulation to fear without being exposed to any real threat. Indeed, this is an inability to realistically assess the situations faced by the individual (Kring \& Johson, 2017). One of the essential functions of psychodrama is to give individuals the chance to test the real threat. In psychodrama scenes, individuals question some realities in their lives. They can recognize various things they are unable to realize in daily life and have a chance to question certain situations they accept as absolute reality (Dökmen, 1995). The psychodrama help individuals discover reality with actions, which might decrease anxiety levels. The participants in the psychodrama mainly considered the anxieties for their future self, their relatives, and life stories. Techniques such as role-playing and impersonating in psychodrama might have provided a more realistic assessment of the situation, about which they felt anxious.

When the effect of psychodrama on subjective well-being levels was considered, it was seen that participants' subjective well-being levels increased in the experimental group from the pre-test to post-test. However, this change was not significant when compared with the control group. It is possible to express that an 11-week psychodrama experience did not significantly increase the participants' subjective well-being in the experimental group. In general, the group activities to increase subjective well-being are applied at least for 12 weeks. Thus, it can be inferred that an 11-week psychodrama program that included future anxieties, anger management issues, and anxieties for the future and the loved ones was insufficient to increase subjective well-being in the experimental group. In addition, the small sample size may have been effective in the non-differentiation of the results obtained from the experimental and control groups.

Additionally, when pre-test subjective well-being score averages of the experimental and control group were investigated, it can be seen that the average scores were close to the highest possible score for this scale. It might stem from the non-clinical research group. Ulloa, Moller, and Sousa-Poza (2013) conducted a review article that analyzed 20 different research and found that there was mainly a U-shape relationship between age and subjective well-being. The high subjective well-being in the first and last years of life reaches the lowest level from the mid-30s to 50s. It can be due to the life period they are in since the group does 
not show any statistically significant increase in subjective well-being as they already have had average subjective well-being.

Unlike the results of this study, Karataş (2014) applied a 12-week psychodrama to the university students and found that subjective well-being increased significantly. However, this effect was not visible in the follow-up measurement conducted ten weeks later. Similarly, Albayrak (2013) applied 12-week psychodrama on university students and found that participants' subjective well-being significantly improved. When the participants of both studies were selected, a subjective well-being scale was applied, and individuals with low subjective well-being were assigned to the experimental and control groups. Different from the current study, this factor might have played a role for psychodrama to be adequate to increase participants' subjective well-being. Kaya and Deniz (2020) applied a 23-week psychodrama. They showed that it significantly enhanced participants' subjective well-being levels, which might stem from the factors such as a relatively long application process and spending the first 10-weeks for the meeting, group unity, and creating a positive group atmosphere.

Consequently, it is possible to state that an 11-week psychodrama program on adults in this study effectively decreased adult trait anxiety levels but had no significant effect on subjective well-being. Including more experience-oriented activities to cope with anxiety to the session's agenda and various sources such as social, emotional, physical, and cognitive might have played a role in the obtained results. The subjective well-being might be influenced by other variables that are not discussed within this study's scope.

This study's main limitation is selecting the participants from voluntary students in a class and the lack of unbiased experimental and control group assignments, which led the participants to possess typical group properties in terms of anxiety and well-being levels. To determine whether any application had a positive effect on the participants in experimental studies, measurements before the program, selecting the participants with lower scores, and unbiased experimental and control group can enable us to see the effects more clearly. Another limitation of the study was the lack of monitoring measurement. Follow-up measurements can show the provisional application's permanent effect, which is the emotional, behavioral, and cognitive changes. In this study, psychodrama was tested as the independent variable. To ensure a positive and significant change in subjective well-being that is influenced by various factors, experimental studies might be conducted by combining psychodrama programs with different methods such as cognitive therapy, behavioral therapy, and positive psychotherapy or by comparing those different methods.

\section{References}

Agha-Bagheri, H., Mohammad-Khani, P., Emrani, S., \& Farahmand, V. (2012). The efficacy of mindfulness-based cognitive therapy group on the increase of subjective well-being and hope in a patient with multiple sclerosis. Journal Clinical Psychology, 4(1), 23-31.

Albayrak, G. (2013). Psiko-eğitim programı ile psikodrama’nın, üniversite ögrencilerinin psikolojik iyi oluş’larına etkisinin karşılaştırılması (Unpublished doctoral thesis, Mersin 
University, Mersin).

Arslan, Ç. (2007). Üniversite öğrencilerinin sürekli kaygı ve kişisel kararsızlık düzeylerinin incelenmesi (Master thesis, Selçuk University, Konya).

Arsu, F., Erbay, E., Gülşen, F., \& Gürgan, U. (2018). Grupla psikolojik danışmanın boşanmış aile çocuklarının öznel iyi oluş ve boşanmaya uyum düzeylerine etkisi. Uluslararası Necatibey Eğitim ve Sosyal Bilimler Araştırmaları Kongresi, Ekim 26-28, 2018, Balıkesir.

Blatner, A. (2000). Foundations of psychodrama. New York: Springer Publication.

Borenstein, M., Hedges, L. V., Higgins, J. P., \& Rothstein, H. R. (2009). Fixed-effect versus random-effects models. Introduction to Meta-Analysis, 77, 85. https://doi.org/10.1002/ 9780470743386.ch13

Büyüköztürk, Ş., Şekercioğlu, G., \& Çokluk, Ö. (2007). Sosyal bilimler için çok değişkenli istatistik: SPSS ve LISREL uygulamaları. Pegem Akademi Yayıncılık.

Canbay, H. (2010). Lise ögrencilerinin öznel iyi oluş düzeyleri ile sosyal beceri düzeyleri arasındaki İlişkinin incelenmesi (Yayımlanmamış Yüksek Lisans Tezi, Dokuz Eylül Üniversitesi, İzmir).

Çardak, M. (2012). Affedicilik yönelimli psiko-eğitim programının affetme ĕgilimi, belirsizliğe tahammülsüzlük, psikolojik iyi oluş, sürekli kaygı ve öfke üzerindeki etkisinin incelenmesi (Unpublished doctoral thesis, Sakarya University, Sakarya).

Çivilidağ, A., Yanar, A., Kızılırmak, B., \& Denizli, T. (2018). Mesleki benlik saygısı, sürekli kayg1 ve yaşam doyumu düzeylerinin incelenmesi. Yaşam Becerileri Psikoloji Dergisi, 2(3), 45-60. https://doi.org/10.31461/ybpd.417509

Cohen, J. (1988). Statistical power analysis for the behavioral sciences (2nd ed.). Hillsdale, NJ: Erlbaum.

Diener, D., \& Ryan, K. (2018). Öznel iyi oluş: Genel bir bakış. Hitit Üniversitesi Sosyal Bilimler Enstitüsü Dergisi, 11(3), 2621-2638.

Diener, E. (2000). Subjective well-being: The science of happiness and a proposal for a national index. American Psychologist, 55(1), 34-43. https://doi.org/10.1037/0003-066X

Diener, E., \& Eunkook, M. S. (2003). Culture and subjective well-being. London: MIT Press. https://doi.org/10.7551/mitpress/2242.001.0001

Dilmaç, B., \& Bozgeyikli, H. (2009). Öğretmen adaylarının öznel iyi olma ve karar verme stillerinin incelenmesi. Erzincan Üniversitesi Eğitim Fakültesi Dergisi, 11(1), 171-187.

Doğan, T., \& Eryılmaz, A. (2013). İki boyutlu benlik saygısı ve öznel iyi oluş arasındaki ilişkilerin incelenmesi. Pamukkale Üniversitesi Eğitim Fakültesi Dergisi, 33, 107-117.

Doğan, T., \& Sapmaz, F. (2012). Kişilerarası ilişki tarzları ve öznel iyi oluş. Türk Ĕgitim Bilimleri Dergisi, 10(3), 585-601. 
Dökmen, Ü. (1995). Sosyometri ve psikodramanın kuramsal temelleri. İstanbul: Sistem Yayıncilik.

Dost, M. (2005). Öznel iyi oluş ölçeğinin geliştirilmesi: Geçerlik güvenirlik çalışması. Türk Psikolojik Danışma ve Rehberlik Dergisi, 3(23), 103-110.

Duran, O. N., \& Tezer, E. (2007). Sanat etkinlikleriyle geliştirilmiş grupla psikolojik danışma programının üniversite öğrencilerinin iyilik hali üzerine etkisi. Türk Psikolojik Danışma ve Rehberlik Dergisi, 28(3), 63-74.

Erbay, L. G., Reyhani, İ., Ünal, S., Özcan, C., Özgöçer, T., Uçar, C., \& Yıldız, S. (2018). Does psychodrama affect perceived stress, anxiety-depression scores and saliva cortisol in patients with depression? Psychiatry Investigation, 15(10), 970-975. https://doi.org/10.30773/ pi.2018.08.11.2

Eryılmaz, A. (2009). Başa çıkma stratejilerinin kişilik özellikleriyle ergen öznel iyi oluşu arasındaki aracı rolü (Yayınlanmamış Doktora Tezi, A.Ü. Eğitim Bilimleri Enstitüsü, Ankara).

Eryılmaz, A. (2010). Öznel iyi oluşu arttırma stratejileri ölçeğinin geliştirilmesi. Türk Psikolojik Danışma ve Rehberlik Dergisi, 33(4), 81-88.

Eryılmaz, A. (2014). Üniversite öğrencileri için geliştirilen öznel iyi oluşu artırma programının etkililiğinin incelenmesi. Mehmet Akif Ersoy Üniversitesi Eğitim Fakültesi Dergisi, 31, 111-128.

Eryılmaz, A., \& Ercan, L. (2011). Öznel iyi oluşun cinsiyet, yaş grupları ve kişilik özellikleri açısından incelenmesi. Türk Psikolojik Danışma ve Rehberlik Dergisi, 36(4), 139-151. https://doi.org/10.14527/9786053180128.06

Görkem, A., \& Tüccar, L. (2018). Psikodramanın üniversite öğrencilerinin kaygı düzeylerine etkisi. Turkish Studies, 13(4), 599-620. https://doi.org/10.7827/TurkishStudies.12737

Gülaçt1, F. (2009). Sosyal beceri eğitimine yönelik bir grup rehberliği programının ögrencilerin, öznel ve psikolojik iyi olma düzeylerine etkisi (Unpublished doctoral thesis, Atatürk University, Erzurum).

Gündoğdu, R., \& Yavuzer, Y. (2012). Eğitim fakültesi öğrencilerinin öznel iyi oluş ve psikolojik ihtiyaçlarının demografik değişkenlere göre incelenmesi. Mehmet Akif Ersoy Üniversitesi Ĕ̈itim Fakültesi Dergisi, 115-131.

Işık, E., \& Bedel, E. (2015). Ergenlerde başa çıkma stratejileri ile öznel iyi oluş arasındaki ilişkiler. Selçuk Üniversitesi Sosyal Bilimler Ensititüsü Dergisi, 34, 53-60.

Kandemir-Bayız, D., \& Kalkan-Oğuzhanoğlu, N. (2020). Kaygı yolculuğu: Psikodramanın psikoloji öğrencilerinin kaygı düzeylerine etkisi. IX Uluslararası Yükseköğretimde Psikolojik Danışmanlık ve Rehberlik Araştırmaları Kongresi. Retrieved from https://www.research gate.net/profile/Duygu_Kandemirci/publication/338402656

Karataş, Z. (2009). Psikodrama ile yapılan grup çalışmasının ergenlerin sürekli kaygı 
düzeylerine etkisi. Çă̆daş Ĕ̈itim Dergisi, 34(360), 31-37.

Karataş, Z. (2014). Effects of psychodrama practice on university students' subjective well-being and hopelessness. Ë̆itim ve Bilim, 39, 117-128.

Kardaş, F., \& Yalçın, İ. (2019). Türkiye'de iyi oluş ile ilgili yapılmış araştırmaların sistematik olarak incelenmesi. Kastamonu Education Journal, 27(4), 1423-1433. https://doi.org/ 10.24106/kefdergi.2799

Kaya, F., \& Deniz, H. (2020). The effects of using psychodrama on the psychological well-being of university students. Perspective Psychiatric Care, 1-8.

Kim, S., Kim, G., \& Ki, J. (2014). Effects of group art therapy combined with breath meditation on the subjective well-being of depressed and anxious adolescents. The Arts in Psychotherapy, 41, 519-526. https://doi.org/10.1016/j.aip.2014.10.002

Korkut-Owen, F., \& Demirbaş-Çelik, N. (2018). Yaşam boyu sağl1klı yaşam ve iyilik hali. Psikiyatride Güncel Yaklaşımlar, 10(4), 430-443 http://doi.org/10.18863/pgy.364108

Korkut-Owen, F., \& Owen, D. W. (2012). İyilik Hali Yıldızı Modeli, uygulanması ve değerlendirilmesi. Uluslararast Avrasya Sosyal Bilimler Dergisi, 3, 24-33.

Korkut-Owen, F., Doğan, T., Demirbaş-Çelik, N., \& Owen, D. W. (2016). Development of TheWell-Star Scale. Journal of Human Sciences, 13, 5013-5031. https://doi.org/10.14687/ jhs.v13i3.4130

Kring, A. N., \& Johnson, A. L. (2017). Anormal psikolojisi. Çev. Muzaffer Şahin. Ankara: Nobel Akademik Yayıncılık.

Kuzucu, Y. (2006). Duyguları fark etmeye ve ifade etmeye yönelik psiko-eğitim programının, üniversite ögrencilerinin duygusal farkındalık düzeylerine, duygulart ifade etme ĕgilimlerine, psikolojik ve öznel iyi oluşlarına etkisi (Doctoral thesis, Ankara University, Ankara).

Marcia, K. (1998). An introduction to psychodrama. In M. Karp, P. Holmes \& K. B. Tauvon (Eds.), The handbook of psychodrama (pp. 3-15). New York: Routledge.

Morgan, R. D. (2004). Groups with offenders and mandated clients. In J. L. DeLucia-Waack, D. A. Gerrity, C. R. Kalodner, \& M. T. Riva (Eds.), Handbook of Group Counseling and Psychotherapy. USA: Sage Publications.

Mosavi, H., \& Haghayegh, S. A. (2019). Efficacy of psychodrama on social anxiety, self-esteem and psychological well-being of university students that met diagnosis of social anxiety disorder. Knowledge \& Research in Applied Psychology, 20(3), 22-30.

Nazar, F., Bahramabadi, M., Delavar, A., \& Gilan, G. (2014). Efficacy of psychodrama techniques in internalizing symptoms (anxiety, depression and somatization) among adolescent girls victims of bullying in kermanshah. Journal Mazandaran University Medical Sciences, 115(24), 142-148.

Ok, E. (2016). Anlam arayışı ĕgitim programının lise öğrencilerinin öznel iyi oluş 
düzeylerine etkisi (Master thesis, Marmara University, İstanbul).

Öner, N., \& Le Compte, A. (1985). Süreksiz Durumluk/Sürekli Kaygı Envanteri El kitabı (2 Basım). İstanbul: Boğaziçi Üniversitesi Yayınları.

Özbek, A., \& Leutz, G. (1987). Psikodrama grup terapilerininsahnesel etkileşimi. Ankara: Has-Say Matbaacilik.

Öztürk, A. (2013). Uludă̆ üniversitesi eğitim fakültesi öğrencilerinin öznel iyi oluş düzeyleri ile tinsellik, iyimserlik, kaygı ve olumsuz duygu düzeyleri arasındaki ilişki (Master thesis, Uludağ University, Bursa).

Saviola, F., Pappaianni, E., Monti, A., Grecucci, A., Jovicich, J., \& Pisapia, N. D. (2020). Trait and state anxiety are mapped differently in the human brain. Scientific Reports, 10, 11112. https://doi.org/10.1038/s41598-020-68008-z

Saygın, Y., \& Arslan, C. (2009). Üniversite öğrencilerinin sosyal destek, benlik saygısı ve öznel iyi oluş düzeylerinin incelenmesi. Selçuk Üniversitesi Ahmet Keleşoğlu Ĕgitim Fakültesi Dergisi, 28, 207-222.

Şencan, H. (2005). Sosyal ve davranışsal ölçümlerde güvenilirlik ve geçerlilik. Ankara: Seçkin Yayınevi.

Tangör, B. B., \& Curun, F. (2016). Psikolojik iyi oluşun yordayıcıları olarak bireysel farklılıklar: özgünlük, benlik saygısı ve sürekli kaygı. Ĕ̆itim ve Öğretim Araştırmaları Dergisi, 5(4), 1-13. https://doi.org/10.16991/INESJOURNAL.1508

Tanhan, F. (2007). Ölüm kaygısıyla baş etme eğitiminin ölüm kaygısı ve psikolojik iyi olma düzeyine etkisi (Doctoral thesis, Ankara University, Ankara).

Tavakoly, M., Namdari, K., \& Esmaili, M. (2014) .Effect of psychodrama-based group training for healthy lifestyle on psychological balance, spiritual well-being and optimism. Journal Life Sciences Biomedicinel, 4, 346-351.

Terzioğlu, C., \& Özkan, B. (2018). Psychodrama and the emotional state of women dealing with in fertility. Sexuality and Disability, 36, 87-99. https://doi.org/10.1007/s11195-0179514-8

Tuzgöl-Dost, M. (2005). Üniversite öğrencilerinin öznel iyi oluş düzeyleri (Doctoral thesis, Hacettepe University, Ankara).

Ulloa, B. F. L., Moller, V., \& Sousa-Poza, A. (2013). How does subjective well-being evolve with age? A literature review. Discussion Paper No. 7328. The Institute for the Study of Labor (IZA). Retrieved May 21, 2020, from http://ftp.iza.org/dp7328.pdf

Ümmet, D., \& Demirci, G. (2017). Yaşam becerileri eğitimi kapsamında yürütülen grupla psikolojik danışma uygulamasının ortaokul öğrencilerinin iyi oluşları üzerindeki etkisi. Marmara Üniversitesi Atatürk Ĕgitim Fakültesi Ĕ̆itim Bilimleri Dergisi, 45, 153-170. https://doi.org/10.15285/maruaebd.263879 


\section{Macrothink}

Journal of Educational Issues

ISSN 2377-2263

2020, Vol. 6, No. 2

Wang, Q., Ding, F., Chen, D., Zhang, X., \& Li, L. (2020). Intervention effect of psychodrama on depression and anxiety: A metaanalysis based on Chinese samples. The Arts in Psychotherapy, 69, 101661. https://doi.org/10.1016/j.aip.2020.101661

\section{Copyright Disclaimer}

Copyright for this article is retained by the author(s), with first publication rights granted to the journal.

This is an open-access article distributed under the terms and conditions of the Creative Commons Attribution license (http://creativecommons.org/licenses/by/3.0/). 